\title{
Planowany rozwój energetycznych sieci przesyłowych w województwie mazowieckim
}

\section{Urszula Gadomska, Beata Gochnio, Elżbieta Polak}

\section{STRESZCZENIE}

Artykuł przedstawia zbiorcze zestawienie zamierzeń inwestycyjnych, dotyczących energetycznych sieci przesyłowych planowanych w województwie mazowieckim, które zostały określone w różnych dokumentach, obowiązujących na koniec 2018 r.

Budowa i przebudowa linii elektroenergetycznych najwyższych napięć oraz gazociągów wysokiego ciśnienia z infrastrukturą towarzyszącą to inwestycje rządowe, realizowane przez przedsiębiorstwa energetyczne, funkcjonujące jako spółki skarbu państwa. Tylko część z planowanych przedsięwzięć (inwestycje ustalone w dokumentach przyjętych przez Sejm lub organy rządu) obligatoryjnie ujęta jest w planie zagospodarowania przestrzennego województwa. W ostatnich latach realizacja większości planowanych przesyłowych sieci energetycznych przebiega według procedur określonych w dwóch tzw. specustawach energetycznych: przesyłowej i gazowej. Zgodnie z ich zapisami, w sprawach związanych z wydaniem decyzji o ustaleniu lokalizacji inwestycji oraz o pozwoleniu na budowę, nie mają zastosowania przepisy o planowaniu i zagospodarowaniu przestrzennym. Oznacza to możliwość realizacji zamierzeń nieujętych w dokumentach planistycznych - zarówno poziomu regionalnego, jak i gminnego.

W związku z tym, że inwestycje energetyczne budzą wielkie protesty społeczne, zasadnym było opracowanie w tym zakresie kompleksowej informacji, która może zostać wykorzystana przez samorządy gminne w procesach negocjacji z przedsiębiorstwami energetycznymi oraz konsultacji z mieszkańcami i organizacjami pozarządowymi.

Słowa kluczowe: sieci energetyczne, inwestycje, specustawy

\section{Wstęp}

Pod pojęciem sieci przesyłowych (transportowych) należy rozumieć - na podstawie ustawy z dnia 10 kwietnia 1997 r. Prawo Energetyczne - „sieć gazową wysokich ciśnień, z wyłączeniem gazociągów kopalnianych i bezpośrednich, albo sieć elektroenergetyczną najwyższych lub wysokich napięć, za której ruch sieciowy jest odpowiedzialny operator systemu przesyłowego". Operatorami systemów przesyłowych w Polsce są dwie spółki akcyjne, których jedynym akcjonariuszem jest Skarb Państwa: Operator Gazociągów Przesyłowych GAZ-SYSTEM S.A. i Polskie Sieci Elektroenergetyczne S.A. (PSE S.A.). W świetle ww. zapisów ustawowych, o uznaniu sieci gazowej wysokiego ciśnienia i sieci elektroenergetycznej najwyższego lub wysokiego napięcia za przesyłową decyduje kryterium dotyczące jej operatora. Ponieważ w województwie mazowieckim sieci tego rodzaju należą także do operatorów dystrybucyjnych, w niniejszym opracowaniu za przesyłowe uznano: 
wszystkie sieci elektroenergetyczne najwyższych napięć (400 kV i $220 \mathrm{kV}$ ), należące głównie do PSE S.A., z wyjątkiem fragmentu sieci $220 \mathrm{kV}$ na terenie Warszawy, którego właścicielem jest innogy Stoen Operator Sp. z o.o. oraz wszystkie gazociągi wysokiego ciśnienia (powyżej 1,6 MPa do $10 \mathrm{MPa}$ włącznie), z których część jest zarządzana przez operatora przesyłowego, a część przez kilku operatorów dystrybucyjnych. Największym z nich jest Polska Spółka Gazownictwa Sp. z o.o. (PSG Sp. z o.o.) - spółka Skarbu Państwa, funkcjonująca w Grupie Kapitałowej Polskie Górnictwo Naftowe i Gazownictwo.

Wyżej wymienione przedsiębiorstwa energetyczne realizują inwestycje na podstawie planów rozwoju w zakresie zaspokojenia obecnego i przyszłego zapotrzebowania na energię i paliwa gazowe, sporządzanych obligatoryjnie, na co najmniej trzyletnie okresy. Przedmiotowe plany uwzględniają m.in. ustalenia krajowych, wojewódzkich i gminnych dokumentów planowania przestrzennego oraz politykę energetyczną państwa.

\section{Realizacja energetycznych sieci przesyłowych na podstawie specustaw}

W ostatnich latach realizacja większości planowanych przesyłowych sieci energetycznych przebiega według procedur określonych w tzw. specustawach energetycznych:

- specustawie gazowej, czyli ustawie z dnia 24 kwietnia 2009 r. o inwestycjach w zakresie terminalu regazyfikacyjnego skroplonego gazu ziemnego w Świnoujściu (dwukrotnie nowelizowanej: w 2014 i 2018 r.),

- $\quad$ specustawie przesyłowej, czyli ustawie z dnia 24 lipca 2015 r. o przygotowaniu i realizacji strategicznych inwestycji w zakresie sieci przesyłowych (znowelizowanej w 2017 r.).

Zgodnie z zapisami ww. ustaw, w sprawach związanych z realizacją określonych $\mathrm{w}$ nich inwestycji nie mają zastosowania przepisy o planowaniu i zagospodarowaniu przestrzennym. Oznacza to możliwość realizacji linii energetycznych z infrastruktura towarzyszącą nieujętych w dokumentach planistycznych - zarówno poziomu regionalnego, jak i gminnego.

Organem właściwym do ustalenia lokalizacji inwestycji, realizowanych $\mathrm{w}$ trybie specustaw, a także wydania pozwoleń na ich budowę jest właściwy miejscowo wojewoda.

Udział samorządu województwa w procesie ustalania lokalizacji ograniczony jest jedynie do przedstawienia opinii (ustawy nie precyzują jej zakresu), która nie jest wiążąca przy wydawaniu decyzji w wyżej wymienionych sprawach. Zarząd Województwa Mazowieckiego, opiniując przedkładane przez inwestorów materiały do wniosków o wydanie decyzji o ustaleniu lokalizacji inwestycji, nie odnosi się do ich szczegółowego usytuowania.

Istotną przesłanką wprowadzenia przedmiotowych specustaw była potrzeba efektywnego i terminowego wykorzystania funduszy Unii Europejskiej (UE) przeznaczonych na realizację strategicznych inwestycji energetycznych w kolejnych okresach programowania.

Specustawa gazowa z 2009 r. miała na celu usprawnienie i przyspieszenie procesów planowania i budowy terminalu regazyfikacyjnego skroplonego gazu ziemnego (tzw. terminalu LNG) w Świnoujściu, który jest obecnie jednym z głównych - alternatywnych 
w stosunku do importu z Rosji - źródeł gazu ziemnego dla Polski. Zapisy przedmiotowej ustawy dotyczą także inwestycji towarzyszących terminalowi, obejmujących elementy strategicznej infrastruktury przesyłowej, umożliwiającej przesył gazu ze Świnoujścia w głąb kraju. W pierwotnej wersji ustawy, na terenie województwa mazowieckiego, była to tylko rozbudowa jednego gazociągu, będącego m.in. głównym kierunkiem zasilania Warszawy. W nowelizacjach z 2014 r. i 2018 r. do ustawy wprowadzono szereg kolejnych inwestycji, w tym budowę gazociągu międzysystemowego Polska - Litwa, integrującego systemy gazownicze krajów UE w basenie Morza Bałtyckiego. Do końca 2018 r. na terenie województwa mazowieckiego, w trybie specustawy gazowej, rozbudowano gazociąg Rembelszczyzna (gm. Nieporęt) - Gustorzyn (woj. kujawsko-pomorskie) oraz przystąpiono do budowy gazociągu z Rembelszczyzny do Elektrociepłowni (EC) Żerań w Warszawie.

Specustawa przesyłowa z 2015 r. ma zastosowanie do wybranych linii elektroenergetycznych najwyższych napięć, uznanych przez UE za projekty wspólnego zainteresowania, które zgodnie z prawem unijnym powinny być traktowane priorytetowo. Inwestycje objęte przepisami przedmiotowej ustawy są niezbędne do: realizacji połączenia transgranicznego Polska - Litwa, wymiany mocy pomiędzy Polską i krajami ościennymi oraz do wyprowadzenia mocy z odnawialnych źródeł energii. Pierwotna wersja tej ustawy uwzględniała na obszarze województwa mazowieckiego budowę pięciu linii 400 kV. W wyniku jej nowelizacji w 2017 r. do inwestycji strategicznych zaliczono budowę kolejnych dwóch linii $400 \mathrm{kV}$ i rozbudowę lub przebudowę dwóch linii $220 \mathrm{kV}$. Do końca 2018 r. w trybie specustawy przesyłowej wybudowano linie: Kozienice - Siedlce Ujrzanów i Ostrołęka - Olsztyn Mątki oraz rozpoczęto realizację linii pomiędzy Warszawą a Siedlcami.

\section{Planowane inwestycje w zakresie energetycznych sieci przesyłowych}

Aktualnymi na koniec 2018 r. dokumentami poziomu krajowego, przyjętymi przez Sejm Rzeczypospolitej Polskiej, Radę Ministrów lub właściwych ministrów, zawierającymi ustalenia dotyczące rozbudowy energetycznych sieci przesyłowych, są:

- dwie specustawy energetyczne - omówione wcześniej,

- Koncepcja przestrzennego zagospodarowania kraju 2030 przyjęta przez Radę Ministrów 13 grudnia 2011 r. (KPZK),

- Kontrakt Terytorialny dla Województwa Mazowieckiego zatwierdzony przez Radę Ministrów w dniu 14 listopada 2014 r.,

- Lista Projektów Strategicznych dla infrastruktury energetycznej w ramach Programu Operacyjnego Infrastruktura $i$ Środowisko 2014-2020 (LPS POIiŚ 2014-2020) zatwierdzona przez Ministra Energii 29 października 2018 r.,

- Strategia na rzecz Odpowiedzialnego Rozwoju do roku 2020 (z perspektywą do 2030 r.), tzw. SOR, przyjęta przez Radę Ministrów w dniu 14 lutego 2017 r.

Większość powyższych dokumentów zawiera imienne wykazy inwestycji energetycznych (KPZK dodatkowo również schematyczne mapy), z wyjątkiem Kontraktu 
Terytorialnego, uwzględniającego przedsięwzięcia priorytetowe w formie zapisów ogólnych (uszczegółowienie znalazło się w POIiŚ 2014-2020) oraz SOR, w której planowane inwestycje przedstawione są wyłącznie na schematycznej mapie. Należy zauważyć, że przedmiotowa mapa (Rysunek 19 w SOR) nie zawiera wszystkich inwestycji wykazanych w specustawach energetycznych.

Inwestycje elektroenergetyczne i gazowe realizowane są przez przedsiębiorstwa energetyczne na podstawie planów rozwoju w zakresie zaspokojenia obecnego i przyszłego zapotrzebowania na energię i paliwa gazowe, sporządzanych obligatoryjnie, na co najmniej trzyletnie okresy (zgodnie z wymogami Prawa Energetycznego). Dokumenty te są okresowo aktualizowane - co 3 lata w zakresie zapotrzebowania na energię elektryczną oraz co 2 lata w zakresie zapotrzebowania na paliwa gazowe. Projekty planów rozwoju są opiniowane przez zarządy województw (ww. ustawa nie precyzuje zakresu tej opinii) i uzgadniane z Prezesem Urzędu Regulacji Energetyki, który jest centralnym organem administracji rządowej.

Ze względu na ograniczony horyzont czasowy, plany przedsiębiorstw nie zawierają wszystkich inwestycji, ustalonych w ww. dokumentach krajowych, zawierają natomiast szereg innych przedsięwzięć, m.in. dotyczących przebudowy i modernizacji istniejących sieci. Aktualne edycje tych planów zostały pozytywnie zaopiniowane przez Zarząd Województwa Mazowieckiego, ze względu na realizację podstawowego celu w zakresie rozwoju systemów energetycznych, określonego w dokumentach strategicznych i planistycznych regionu, jakim jest zapewnienie bezpieczeństwa energetycznego.

Wszystkie planowane $\mathrm{w}$ województwie mazowieckim inwestycje dotyczące systemu elektroenergetycznego najwyższych napięć oraz systemu gazowego wysokiego ciśnienia, określone w dokumentach obowiązujących na koniec 2018 r., zostały zestawione w załączonych tabelach oraz przedstawione na rysunkach. Znaczna część projektowanych sieci znajduje się obecnie w fazie analiz lokalizacyjnych. Należy spodziewać się, że najbardziej konfliktowe będzie ustalenie przebiegu inwestycji liniowych, mimo że niektóre z nich będą realizowane z maksymalnym (w miarę możliwości technicznych) wykorzystaniem tras sieci istniejących. 
Tabela 1. Planowane inwestycje w zakresie sieci elektroenergetycznych najwyższych napięć (stan na koniec 2018 r.)

\begin{tabular}{|c|c|c|c|c|c|}
\hline Lp. & Inwestycja & Parametry & $\begin{array}{l}\text { Lokalizacja [gminy } \\
\text { w woj. mazowieckim] }\end{array}$ & $\begin{array}{l}\text { Dokument } \\
\text { uwzględniający } \\
\text { inwestycję }\end{array}$ & Inwestor \\
\hline \multirow[t]{5}{*}{1.} & \multirow[t]{5}{*}{$\begin{array}{l}\text { Budowa linii } \\
\text { Ostrołęka - } \\
\text { Stanisławów } \\
\text { (z wykorzystaniem } \\
\text { trasy istniejącej linii } \\
220 \mathrm{kV} \text { ) }\end{array}$} & \multirow{5}{*}{$400 \mathrm{kV}$} & \multirow{5}{*}{$\begin{array}{l}\text { Istniejąca linia przebiega } \\
\text { w gminach: m. Ostrołęka, } \\
\text { Rzekuń, Troszyn, } \\
\text { Czerwin, Goworowo, } \\
\text { Wąsewo, Długosiodło, } \\
\text { Brańszczyk, Wyszków, } \\
\text { Łochów, Jadów, } \\
\text { Strachówka, Korytnica, } \\
\text { Dobre, Stanisławów }\end{array}$} & $\begin{array}{l}\text { Specustawa } \\
\text { przesyłowa } \\
\text { (pkt } 3 \text { wykazu } \\
\text { strategicznych } \\
\text { inwestycji) } \\
\end{array}$ & \multirow{5}{*}{ PSE S.A. } \\
\hline & & & & KPZK & \\
\hline & & & & LPS POIiŚ 2014-2020 & \\
\hline & & & & SOR & \\
\hline & & & & $\begin{array}{l}\text { Plan rozwoju PSE S.A. } \\
\text { na lata 2016-2025 }\end{array}$ & \\
\hline \multirow[t]{2}{*}{2.} & \multirow{2}{*}{$\begin{array}{l}\text { Budowa linii } \\
\text { Kozienice - Miłosna } \\
\text { (z wykorzystaniem } \\
\text { trasy istniejącej } \\
\text { linii } 400 \mathrm{kV} \text { ) wraz } \\
\text { z rozbudową stacji } \\
400 / 220 / 110 \mathrm{kV} \\
\text { Miłosna }\end{array}$} & \multirow[t]{2}{*}{$400 \mathrm{kV}$} & \multirow{2}{*}{$\begin{array}{l}\text { Wg uzasadnienia } \\
\text { do projektu zmiany } \\
\text { specustawy przesyłowej } \\
\text { - wzdłuż istniejącej linii } \\
\text { w gminach: Kozienice, } \\
\text { Magnuszew, Wilga, } \\
\text { Sobienie Jeziory, } \\
\text { Karczew, Celestynów, } \\
\text { m. Otwock, Wiązowna, } \\
\text { Halinów, m. Sulejówek }\end{array}$} & $\begin{array}{l}\text { Specustawa } \\
\text { przesyłowa } \\
\text { (pkt } 24 \text { wykazu } \\
\text { strategicznych } \\
\text { inwestycji) }\end{array}$ & \multirow[t]{2}{*}{ PSE S.A. } \\
\hline & & & & $\begin{array}{l}\text { Wniosek lokalizacyjny } \\
\text { na podst. specustawy } \\
\text { dla rozbudowy stacji } \\
\text { Miłosna }\end{array}$ & \\
\hline
\end{tabular}




\begin{tabular}{|c|c|c|c|c|c|}
\hline Lp. & Inwestycja & Parametry & $\begin{array}{l}\text { Lokalizacja [gminy } \\
\text { w woj. mazowieckim] }\end{array}$ & $\begin{array}{l}\text { Dokument } \\
\text { uwzględniający } \\
\text { inwestycję }\end{array}$ & Inwestor \\
\hline \multirow[t]{3}{*}{3.} & \multirow{3}{*}{$\begin{array}{l}\text { Budowa linii wraz } \\
\text { ze zmianą układu } \\
\text { sieci najwyższych } \\
\text { napięć pomiędzy } \\
\text { aglomeracją } \\
\text { warszawską } \\
\text { a Siedlcami } \\
\text { (pomiędzy } \\
\text { nacięciami linii } \\
\text { Stanisławów } \\
\text { - Narew, } \\
\text { Stanisławów - } \\
\text { Siedlce Ujrzanów, } \\
\text { Kozienice - Siedlce } \\
\text { Ujrzanów) }\end{array}$} & \multirow{3}{*}{$400 \mathrm{kV}$} & \multirow[t]{3}{*}{$\begin{array}{l}\text { Wg wydanej decyzji } \\
\text { lokalizacyjnej- } \\
\text { w gminach: Wierzbno, } \\
\text { Dobre, Kałuszyn, } \\
\text { Cegłów, Latowicz, } \\
\text { Wodynie }\end{array}$} & $\begin{array}{l}\text { Specustawa } \\
\text { przesyłowa } \\
\text { (pkt } 25 \text { wykazu } \\
\text { strategicznych } \\
\text { inwestycji) }\end{array}$ & \multirow{3}{*}{ PSE S.A. } \\
\hline & & & & SOR & \\
\hline & & & & $\begin{array}{l}\text { Decyzja lokalizacyjna } \\
\text { na podst. specustawy }\end{array}$ & \\
\hline \multirow[t]{4}{*}{4.} & \multirow[t]{4}{*}{$\begin{array}{l}\text { Budowa linii } \\
\text { Kozienice - } \\
\text { Ołtarzew }\end{array}$} & \multirow[t]{4}{*}{$400 \mathrm{kV}$} & \multirow[t]{4}{*}{$\begin{array}{l}\text { W trakcie analiz - } \\
\text { pomiędzy gminami: } \\
\text { Kozienice i Ożarów } \\
\text { Mazowiecki }\end{array}$} & $\begin{array}{l}\text { Specustawa } \\
\text { przesyłowa } \\
\text { (pkt } 7 \text { wykazu } \\
\text { strategicznych } \\
\text { inwestycji) }\end{array}$ & \multirow[t]{4}{*}{ PSE S.A. } \\
\hline & & & & KPZK & \\
\hline & & & & SOR & \\
\hline & & & & $\begin{array}{l}\text { Plan rozwoju PSE S.A. } \\
\text { na lata 2016-2025 }\end{array}$ & \\
\hline \multirow[t]{2}{*}{5.} & \multirow[t]{2}{*}{$\begin{array}{l}\text { Budowa linii Płock } \\
\text { - Olsztyn Mątki }\end{array}$} & \multirow[t]{2}{*}{$400 \mathrm{kV}$} & \multirow[t]{2}{*}{$\begin{array}{l}\text { W trakcie analiz - } \\
\text { pomiędzy gminą } \\
\text { Stara Biała a granicą } \\
\text { województw: } \\
\text { mazowieckiego } \\
\text { i kujawsko-pomorskiego }\end{array}$} & $\begin{array}{l}\text { Specustawa } \\
\text { przesyłowa } \\
\text { (pkt } 5 \text { wykazu } \\
\text { strategicznych } \\
\text { inwestycji) } \\
\end{array}$ & \multirow[t]{2}{*}{ PSE S.A. } \\
\hline & & & & KPZK & \\
\hline \multirow[t]{2}{*}{6.} & \multirow{2}{*}{$\begin{array}{l}\text { Budowa linii } \\
\text { Siedlce Ujrzanów } \\
\text { - linia Narew - } \\
\text { Stanisławów }\end{array}$} & \multirow{2}{*}{$400 \mathrm{kV}$} & \multirow{2}{*}{$\begin{array}{l}\text { W trakcie analiz - } \\
\text { pomiędzy gminą } \\
\text { Siedlce a linią Narew - } \\
\text { Stanisławów }\end{array}$} & KPZK & \multirow{2}{*}{ PSE S.A. } \\
\hline & & & & SOR & \\
\hline
\end{tabular}




\begin{tabular}{|c|c|c|c|c|c|}
\hline Lp. & Inwestycja & Parametry & $\begin{array}{l}\text { Lokalizacja [gminy } \\
\text { w woj. mazowieckim] }\end{array}$ & $\begin{array}{l}\text { Dokument } \\
\text { uwzględniający } \\
\text { inwestycję }\end{array}$ & Inwestor \\
\hline 7. & $\begin{array}{l}\text { Budowa linii } \\
\text { Ostrołęka - Ełk } \\
\text { (z wykorzystaniem } \\
\text { trasy istniejącej linii } \\
220 \mathrm{kV} \text { ) }\end{array}$ & $400 \mathrm{kV}$ & $\begin{array}{l}\text { Istniejąca linia przebiega } \\
\text { w gminach: m. Ostrołęka, } \\
\text { Rzekuń, Lelis }\end{array}$ & SOR & PSE S.A. \\
\hline 8. & $\begin{array}{l}\text { Budowa linii } \\
\text { Kozienice - } \\
\text { Puławy(jako } \\
\text { wpięcie w istniejącą } \\
\text { linię Kozienice - } \\
\text { Ostrowiec) }\end{array}$ & $400 \mathrm{kV}$ & $\begin{array}{l}\text { W trakcie analiz - } \\
\text { pomiędzy gminą } \\
\text { Kozienice a granica } \\
\text { województw: } \\
\text { mazowieckiegoi } \\
\text { lubelskiego }\end{array}$ & $\begin{array}{l}\text { Plan rozwoju PSE S.A. } \\
\text { na lata 2016-2025 }\end{array}$ & PSE S.A. \\
\hline 9. & $\begin{array}{l}\text { Budowa linii Lublin } \\
\text { Wschód - Siedlce } \\
\text { Ujrzanów }\end{array}$ & $400 \mathrm{kV}$ & $\begin{array}{l}\text { W trakcie analiz - } \\
\text { pomiędzy gminą Siedlce } \\
\text { a granicą województw: } \\
\text { mazowieckiego } \\
\text { i lubelskiego }\end{array}$ & KPZK & PSE S.A. \\
\hline 10. & $\begin{array}{l}\text { Rozbudowa lub } \\
\text { przebudowa linii } \\
\text { Kozienice - Rożki }\end{array}$ & $220 \mathrm{kV}$ & $\begin{array}{l}\text { Wg uzasadnienia } \\
\text { do projektu zmiany } \\
\text { specustawy przesyłowej } \\
\text { - wzdłuż istniejącej linii } \\
\text { w gminach: Kozienice, } \\
\text { Głowaczów, Jastrzębia, } \\
\text { m. Radom, Jedlińsk, } \\
\text { Zakrzew, Wolanów, } \\
\text { Kowala }\end{array}$ & $\begin{array}{l}\text { Specustawa } \\
\text { przesyłowa } \\
\text { (pkt } 27 \text { wykazu } \\
\text { strategicznych } \\
\text { inwestycji) }\end{array}$ & PSE S.A. \\
\hline 11. & $\begin{array}{l}\text { Rozbudowa lub } \\
\text { przebudowa linii } \\
\text { Rożki - Kielce }\end{array}$ & $220 \mathrm{kV}$ & $\begin{array}{l}\text { Wg uzasadnienia } \\
\text { do projektu zmiany } \\
\text { specustawy przesyłowej } \\
\text { - wzdłuż istniejącej linii } \\
\text { w gminach: Kowala, } \\
\text { Orońsko, Szydłowiec, } \\
\text { Chlewiska }\end{array}$ & $\begin{array}{l}\text { Specustawa } \\
\text { przesyłowa } \\
\text { (pkt } 28 \text { wykazu } \\
\text { strategicznych } \\
\text { inwestycji) }\end{array}$ & PSE S.A. \\
\hline
\end{tabular}




\begin{tabular}{|c|c|c|c|c|c|}
\hline Lp. & Inwestycja & Parametry & $\begin{array}{l}\text { Lokalizacja [gminy } \\
\text { w woj. mazowieckim] }\end{array}$ & $\begin{array}{l}\text { Dokument } \\
\text { uwzględniający } \\
\text { inwestycję }\end{array}$ & Inwestor \\
\hline 12. & $\begin{array}{l}\text { Modernizacja linii } \\
\text { Płock - Miłosna }\end{array}$ & $400 \mathrm{kV}$ & $\begin{array}{l}\text { Istniejąca linia przebiega } \\
\text { w gminach: Stara Biała, } \\
\text { Bielsk, Radzanowo, } \\
\text { Bulkowo, Bodzanów, } \\
\text { Mała Wieś, Wyszogród, } \\
\text { Młodzieszyn, Brochów, } \\
\text { Sochaczew, Kampinos, } \\
\text { Błonie, Leszno, Ożarów } \\
\text { Mazowiecki, Stare } \\
\text { Babice, Izabelin, } \\
\text { m. Warszawa, Łomianki, } \\
\text { Jabłonna, Nieporęt, } \\
\text { Radzymin, Klembów, } \\
\text { Wołomin, Poświętne, } \\
\text { m. Zielonka, Halinów, } \\
\text { m. Sulejówek, Wiązowna }\end{array}$ & $\begin{array}{l}\text { Plan rozwoju PSE S.A. } \\
\text { na lata 2016-2025 }\end{array}$ & $\begin{array}{l}\text { PSE S.A. } \\
\text { PSE S.A. }\end{array}$ \\
\hline 13. & $\begin{array}{l}\text { Modernizacja } \\
\text { linii Grudziądz } \\
\text { Węgrowo - Płock }\end{array}$ & $400 \mathrm{kV}$ & $\begin{array}{l}\text { Istniejąca linia przebiega } \\
\text { w gminach: Szczutowo, } \\
\text { Sierpc, Mochowo, } \\
\text { Gozdowo, Stara Biała }\end{array}$ & $\begin{array}{l}\text { Plan rozwoju PSE S.A. } \\
\text { na lata } 2016-2025\end{array}$ & PSE S.A. \\
\hline 14. & $\begin{array}{l}\text { Budowa linii } \\
\text { EC Siekierki } \\
\text { - Warszawa } \\
\text { Towarowa }\end{array}$ & $220 \mathrm{kV}$ & m. Warszawa & KPZK & PSE S.A. \\
\hline 15. & $\begin{array}{l}\text { Budowa linii } \\
\text { EC Siekierki - } \\
\text { Piaseczno }\end{array}$ & $220 \mathrm{kV}$ & $\begin{array}{l}\text { Wg gminnych } \\
\text { dokumentów } \\
\text { planistycznych - } \\
\text { w gminach: } \\
\text { m. Warszawa, Piaseczno } \\
\text { i ew. Konstancin-Jeziorna }\end{array}$ & KPZK & PSE S.A. \\
\hline 16. & $\begin{array}{l}\text { Budowa linii } \\
\text { Miłosna - EC } \\
\text { Siekierki }\end{array}$ & $220 \mathrm{kV}$ & $\begin{array}{l}\text { Wg gminnych } \\
\text { dokumentów } \\
\text { planistycznych - } \\
\text { w gminach: Wiązowna, } \\
\text { m. Sulejówek, } \\
\text { m. Warszawa }\end{array}$ & KPZK & PSE S.A. \\
\hline
\end{tabular}




\begin{tabular}{|c|c|c|c|c|c|}
\hline Lp. & Inwestycja & Parametry & $\begin{array}{l}\text { Lokalizacja [gminy } \\
\text { w woj. mazowieckim] }\end{array}$ & $\begin{array}{l}\text { Dokument } \\
\text { uwzględniający } \\
\text { inwestycję }\end{array}$ & Inwestor \\
\hline 17. & $\begin{array}{l}\text { Modernizacja linii } \\
\text { Ołtarzew - Mory }\end{array}$ & $220 \mathrm{kV}$ & $\begin{array}{l}\text { Istniejąca linia przebiega } \\
\text { w gminach: Ożarów } \\
\text { Mazowiecki, } \\
\text { m. Warszawa }\end{array}$ & $\begin{array}{l}\text { Plan rozwoju PSE S.A. } \\
\text { na lata 2016-2025 }\end{array}$ & PSE S.A. \\
\hline 18. & $\begin{array}{l}\text { Modernizacja linii } \\
\text { Mory - Warszawa } \\
\text { Towarowa }\end{array}$ & $220 \mathrm{kV}$ & $\begin{array}{l}\text { Istniejąca linia przebiega } \\
\text { w m. Warszawa }\end{array}$ & $\begin{array}{l}\text { Plan rozwoju RWE } \\
\text { Stoen Operator Sp. } \\
\text { z o.o. na lata 2017- } \\
2022 \text { (obecnie innogy } \\
\text { Stoen Operator Sp. } \\
\text { z o.o.) }\end{array}$ & $\begin{array}{l}\text { innogy } \\
\text { Stoen } \\
\text { Operator } \\
\text { Sp. z o.o. }\end{array}$ \\
\hline \multirow[t]{3}{*}{19.} & \multirow{3}{*}{$\begin{array}{l}\text { Budowa stacji } \\
\text { Wyszków } \\
\text { (wprowadzonej do } \\
\text { linii Ostrołęka - } \\
\text { Stanisławów) }\end{array}$} & \multirow{3}{*}{$\begin{array}{l}400(220) \\
/ 110 \mathrm{kV}\end{array}$} & \multirow[t]{3}{*}{$\begin{array}{l}\text { Brańszczyk i ew. } \\
\text { Wyszków }\end{array}$} & KPZK & \multirow{3}{*}{ PSE S.A } \\
\hline & & & & LPS POIiŚ 2014-2020 & \\
\hline & & & & $\begin{array}{l}\text { Plan rozwoju PSE S.A. } \\
\text { na lata 2016-2025 }\end{array}$ & \\
\hline 20. & $\begin{array}{l}\text { Budowa stacji EC } \\
\text { Siekierki (poprzez } \\
\text { rozbudowę } \\
\text { istniejącej 110/SN) }\end{array}$ & $\begin{array}{c}400(220) / 110 \\
\mathrm{kV}\end{array}$ & m. Warszawa & KPZK & PSE S.A. \\
\hline \multirow[t]{2}{*}{21.} & \multirow{2}{*}{$\begin{array}{l}\text { Budowa stacji } \\
\text { Warszawa } \\
\text { Praga (poprzez } \\
\text { rozbudowę } \\
\text { istniejącej 110/SN) }\end{array}$} & \multirow[b]{2}{*}{$220 / 110 \mathrm{kV}$} & \multirow[b]{2}{*}{ m. Warszawa } & KPZK & \multirow[b]{2}{*}{ PSE S.A. } \\
\hline & & & & $\begin{array}{l}\text { Plan rozwoju PSE S.A. } \\
\text { na lata 2016-2025 }\end{array}$ & \\
\hline \multirow[t]{2}{*}{22.} & \multirow{2}{*}{$\begin{array}{l}\text { Rozbudowa stacji } \\
\text { Ostrołęka (II etap) }\end{array}$} & \multirow[b]{2}{*}{$\begin{array}{c}\text { 400/220/110 } \\
\text { kV }\end{array}$} & \multirow[b]{2}{*}{ m. Ostrołęka } & KPZK & \multirow[b]{2}{*}{ PSE S.A } \\
\hline & & & & $\begin{array}{l}\text { Plan rozwoju PSE S.A. } \\
\text { na lata 2016-2025 }\end{array}$ & \\
\hline 23. & $\begin{array}{l}\text { Rozbudowa stacji } \\
\text { Stanisławów }\end{array}$ & $400 / 110 \mathrm{kV}$ & Stanisławów & $\begin{array}{l}\text { Plan rozwoju PSE S.A. } \\
\text { na lata 2016-2025 }\end{array}$ & PSE S.A. \\
\hline 24. & $\begin{array}{l}\text { Rozbudowa stacji } \\
\text { Mościska }\end{array}$ & $400 / 110 \mathrm{kV}$ & m. Warszawa & $\begin{array}{l}\text { Plan rozwoju PSE S.A. } \\
\text { na lata 2016-2025 }\end{array}$ & PSE S.A. \\
\hline 25. & $\begin{array}{l}\text { Rozbudowa stacji } \\
\text { Mory }\end{array}$ & $220 / 110 \mathrm{kV}$ & m. Warszawa & $\begin{array}{l}\text { Plan rozwoju PSE S.A. } \\
\text { na lata 2016-2025 }\end{array}$ & PSE S.A. \\
\hline 26. & $\begin{array}{l}\text { Rozbudowa stacji } \\
\text { Piaseczno }\end{array}$ & $220 / 110 \mathrm{kV}$ & Piaseczno & $\begin{array}{l}\text { Plan rozwoju PSE S.A. } \\
\text { na lata 2016-2025 }\end{array}$ & PSE S.A. \\
\hline
\end{tabular}




\begin{tabular}{|l|l|l|l|l|l|}
\hline Lp. & Inwestycja & Parametry & $\begin{array}{l}\text { Lokalizacja Igminy } \\
\text { w woj. mazowieckim] }\end{array}$ & $\begin{array}{l}\text { Dokument } \\
\text { uwzględniający } \\
\text { inwestycję }\end{array}$ & Inwestor \\
\hline 27. & $\begin{array}{l}\text { Modernizacja stacji } \\
\text { Rożki }\end{array}$ & $220 / 110 \mathrm{kV}$ & Kowala & $\begin{array}{l}\text { Plan rozwoju PSE S.A. } \\
\text { na lata 2016-2025 }\end{array}$ & PSE S.A. \\
\hline 28. & $\begin{array}{l}\text { Modernizacja } \\
\text { stacji Warszawa } \\
\text { Towarowa }\end{array}$ & $220 / 110 \mathrm{kV}$ & $\begin{array}{l}\text { Plan rozwoju RWE } \\
\text { Stoen Operator Sp. } \\
\text { z o.o. na lata 2017- } \\
\text { 2022 (obecnie innogy } \\
\text { Stoen Operator Sp. } \\
\text { z o.o.) }\end{array}$ & $\begin{array}{l}\text { Operator } \\
\text { Sp. z o.o. }\end{array}$ \\
& m. Warszawa \\
\hline
\end{tabular}

Źródło: opracowanie własne na podstawie: specustawy przesyłowej, KPZK, LPS POliŚ, SOR, planów rozwoju i danych operatorów elektroenergetycznego systemu przesyłowego, decyzji lub wniosków lokalizacyjnych 
Tabela 2. Planowane inwestycje w zakresie sieci gazowych wysokiego ciśnienia (stan na koniec 2018 r.)

\begin{tabular}{|c|c|c|c|c|c|}
\hline Lp. & Inwestycja & Parametry & $\begin{array}{l}\text { Lokalizacja [gminy } \\
\text { w woj. mazowieckim] }\end{array}$ & $\begin{array}{l}\text { Dokument } \\
\text { uwzględniający } \\
\text { inwestycję }\end{array}$ & Inwestor \\
\hline \multirow[t]{8}{*}{1.} & \multirow{8}{*}{$\begin{array}{l}\text { Budowa } \\
\text { międzysystemowego } \\
\text { gazociągu } \\
\text { stanowiącego } \\
\text { połączenie systemów } \\
\text { przesyłowych } \\
\text { Rzeczypospolitej } \\
\text { Polskiej i Republiki } \\
\text { Litewskiej }\end{array}$} & \multirow{8}{*}{ DN 700} & \multirow{8}{*}{$\begin{array}{l}\text { I wariant - } \\
\text { powiązanie z tłocznią } \\
\text { Rembelszczyzna } \\
\text { w gminie Nieporęt } \\
\text { (odstąpiono od } \\
\text { realizacji) } \\
\text { II wariant - } \\
\text { powiązanie z tłocznią } \\
\text { Hołowczycew gminie } \\
\text { Sarnaki, wg wniosków } \\
\text { lokalizacyjnych - } \\
\text { w gminach: Sarnaki } \\
\text { Boguty-Pianki, } \\
\text { Andrzejewo }\end{array}$} & $\begin{array}{l}\text { Specustawa gazowa } \\
\text { (art. } 38 \text { pkt } 2 \text { lit. x) }\end{array}$ & \multirow{8}{*}{$\begin{array}{l}\text { GAZ- } \\
\text { SYSTEM } \\
\text { S.A. }\end{array}$} \\
\hline & & & & KPZK (I wariant) & \\
\hline & & & & SOR (II wariant) & \\
\hline & & & & Plan rozwoju GAZ- & \\
\hline & & & & SYSTEM S.A. na lata & \\
\hline & & & & & \\
\hline & & & & $\begin{array}{l}\text { SYSTEM S.A. na lata } \\
\text { 2018-2027 (II wariant) }\end{array}$ & \\
\hline & & & & $\begin{array}{l}\text { Wnioski lokalizacyjne } \\
\text { na podst. specustawy } \\
\text { dla fragmentów } \\
\text { inwestycji o relacji } \\
\text { Hołowczyce - Rudka } \\
\text { Skroda w woj. } \\
\text { podlaskim (II wariant) }\end{array}$ & \\
\hline
\end{tabular}




\begin{tabular}{|c|c|c|c|c|c|}
\hline Lp. & Inwestycja & Parametry & $\begin{array}{l}\text { Lokalizacja [gminy } \\
\text { w woj. mazowieckim] }\end{array}$ & $\begin{array}{l}\text { Dokument } \\
\text { uwzględniający } \\
\text { inwestycję }\end{array}$ & Inwestor \\
\hline \multirow[t]{18}{*}{2.} & \multirow{18}{*}{$\begin{array}{l}\text { Budowa gazociągu } \\
\text { Rembelszczyzna } \\
\text { - Mory - Wola } \\
\text { Karczewska } \\
\text { (rozbudowa } \\
\text { zachodniej części } \\
\text { "warszawskiego } \\
\text { pierścienia } \\
\text { gazowego") }\end{array}$} & \multirow{18}{*}{ DN 700} & \multirow{18}{*}{$\begin{array}{l}\text { Wg wniosku } \\
\text { lokalizacyjnego - } \\
\text { wzdłuż istniejącego } \\
\text { gazociągu } \\
\text { (częściowo z dużym } \\
\text { przesunięciem) - } \\
\text { w gminach: Nieporęt, } \\
\text { Jabłonna, m. Warszawa, } \\
\text { Łomianki, Stare } \\
\text { Babice, Ożarów } \\
\text { Mazowiecki, } \\
\text { m. Piastów, m. Pru- } \\
\text { szków, Brwinów, } \\
\text { Michałowice, } \\
\text { Nadarzyn, Raszyn, } \\
\text { Lesznowola, } \\
\text { Piaseczno, Góra } \\
\text { Kalwaria, Karczew, } \\
\text { m. Otwock, Celesty- } \\
\text { nów, Wiązowna }\end{array}$} & Specustawa gazowa & \multirow{18}{*}{$\begin{array}{l}\text { GAZ- } \\
\text { SYSTEM } \\
\text { S.A. }\end{array}$} \\
\hline & & & & (art. 38 pkt 2 lit. r) & \\
\hline & & & & & \\
\hline & & & & & \\
\hline & & & & & \\
\hline & & & & \multirow{3}{*}{ SOR } & \\
\hline & & & & & \\
\hline & & & & & \\
\hline & & & & Plan rozwoju GAZ- & \\
\hline & & & & SYSTEM S.A. na lata & \\
\hline & & & & 2018-2027 & \\
\hline & & & & & \\
\hline & & & & Wniosek lokalizacyiny & \\
\hline & & & & na podst. specustawy & \\
\hline & & & & dla fragmentu & \\
\hline & & & & inwestycji o relacji & \\
\hline & & & & Rembelszczyzna - & \\
\hline & & & & Mory & \\
\hline \multirow[t]{6}{*}{3.} & \multirow{6}{*}{$\begin{array}{l}\text { Budowa gazociagu } \\
\text { Rembelszczyzna - } \\
\text { Wronów (rozbudowa } \\
\text { istniejącego } \\
\text { gazociągu) }\end{array}$} & \multirow{6}{*}{ DN 1000} & \multirow{6}{*}{$\begin{array}{l}\text { W trakcie analiz - } \\
\text { pomiędzy gminami } \\
\text { Nieporęt a granicą } \\
\text { województw: } \\
\text { mazowieckiego } \\
\text { i lubelskiego }\end{array}$} & Specustawa gazowa & \multirow{6}{*}{$\begin{array}{l}\text { GAZ- } \\
\text { SYSTEM } \\
\text { S.A. }\end{array}$} \\
\hline & & & & (art. 38 pkt 2 lit. q) & \\
\hline & & & & KPZK & \\
\hline & & & & Plan rozwoju GAZ- & \\
\hline & & & & SYSTEM S.A. na lata & \\
\hline & & & & 2018-2027 & \\
\hline \multirow[t]{9}{*}{4.} & \multirow{9}{*}{$\begin{array}{l}\text { Budowa gazociagu } \\
\text { Gustorzyn - Tworóg } \\
\text { (w tym rozbudowa } \\
\text { istniejącego } \\
\text { gazociągu Gustorzyn } \\
\text { - Leśniewice) }\end{array}$} & \multirow{9}{*}{ b. d. } & \multirow[t]{9}{*}{$\mathrm{W}$ trakcie analiz } & specustawa gazowa & \multirow{9}{*}{$\begin{array}{l}\text { GAZ- } \\
\text { SYSTEM } \\
\text { S.A. }\end{array}$} \\
\hline & & & & (art. 38 pkt 2 lit. s) & \\
\hline & & & & SOR (tylko fragment & \\
\hline & & & & inwestycji) & \\
\hline & & & & Plan rozwoju GAZ- & \\
\hline & & & & SYSTEM S.A. na & \\
\hline & & & & lata 2018-2027 & \\
\hline & & & & (tylkofragment & \\
\hline & & & & inwestycji) & \\
\hline
\end{tabular}




\begin{tabular}{|c|c|c|c|c|c|}
\hline Lp. & Inwestycja & Parametry & $\begin{array}{l}\text { Lokalizacja [gminy } \\
\text { w woj. mazowieckim] }\end{array}$ & $\begin{array}{l}\text { Dokument } \\
\text { uwzględniający } \\
\text { inwestycję }\end{array}$ & Inwestor \\
\hline \multirow[t]{3}{*}{5.} & \multirow[t]{3}{*}{$\begin{array}{l}\text { Budowa gazociągu } \\
\text { Wronów - Odolanów }\end{array}$} & \multirow{3}{*}{ DN 1000} & \multirow{3}{*}{$\begin{array}{l}\text { Wg wniosku } \\
\text { lokalizacyjnego } \\
\text { - w gminach: } \\
\text { Mogielnica, } \\
\text { Wyśmierzyce, } \\
\text { Radzanów, Stara } \\
\text { Błotnica, Białobrzegi, } \\
\text { Jedlińsk, Głowaczów, } \\
\text { Kozienice, Sieciechów, } \\
\text { Gniewoszów }\end{array}$} & $\begin{array}{l}\text { Specustawa gazowa } \\
\text { (art. } 38 \text { pkt } 2 \text { lit. t) }\end{array}$ & \multirow{3}{*}{$\begin{array}{l}\text { GAZ- } \\
\text { SYSTEM } \\
\text { S.A. }\end{array}$} \\
\hline & & & & $\begin{array}{l}\text { Plan rozwoju GAZ- } \\
\text { SYSTEM S.A. na lata } \\
2018-2027\end{array}$ & \\
\hline & & & & $\begin{array}{l}\text { Wniosek lokalizacyjny } \\
\text { na podst. specustawy } \\
\text { dla fragmentu } \\
\text { inwestycji o relacji } \\
\text { Wronów - Rawa } \\
\text { Mazowiecka }\end{array}$ & \\
\hline 6. & $\begin{array}{l}\text { Budowa gazociągu } \\
\text { Płońsk - } \\
\text { Olsztyn(rozbudowa } \\
\text { istniejącego } \\
\text { gazociągu) }\end{array}$ & b. d. & W trakcie analiz & $\begin{array}{l}\text { Specustawa gazowa } \\
\text { (art. } 38 \text { pkt } 2 \text { lit. u) }\end{array}$ & $\begin{array}{l}\text { GAZ- } \\
\text { SYSTEM } \\
\text { S.A. }\end{array}$ \\
\hline \multirow[t]{3}{*}{7.} & \multirow[t]{3}{*}{$\begin{array}{l}\text { Budowa gazociagu } \\
\text { Rembelszczyzna - EC } \\
\text { Żerań }\end{array}$} & \multirow[t]{3}{*}{ DN 500} & \multirow[t]{3}{*}{$\begin{array}{l}\text { Wg wydanej decyzji } \\
\text { lokalizacyjnej - } \\
\text { w gminach: Nieporęt, } \\
\text { m. Warszawa }\end{array}$} & $\begin{array}{l}\text { Specustawa gazowa } \\
\text { (art. } 38 \text { pkt } 2 \text { lit. zh: } \\
\text { „Budowa przyłaczy } \\
\text { i gazociagów stużacych } \\
\text { do przyłaczenia do } \\
\text { systemu przesyłowego } \\
\text { gazowego podmiotów } \\
\text { przyłaczanych") }\end{array}$ & \multirow[t]{3}{*}{$\begin{array}{l}\text { GAZ- } \\
\text { SYSTEM } \\
\text { S.A. }\end{array}$} \\
\hline & & & & $\begin{array}{l}\text { Plan rozwoju PSG Sp. } \\
\text { z o.o. na lata 2018-2022 }\end{array}$ & \\
\hline & & & & $\begin{array}{l}\text { Decyzja lokalizacyjna } \\
\text { na podst. specustawy }\end{array}$ & \\
\hline
\end{tabular}




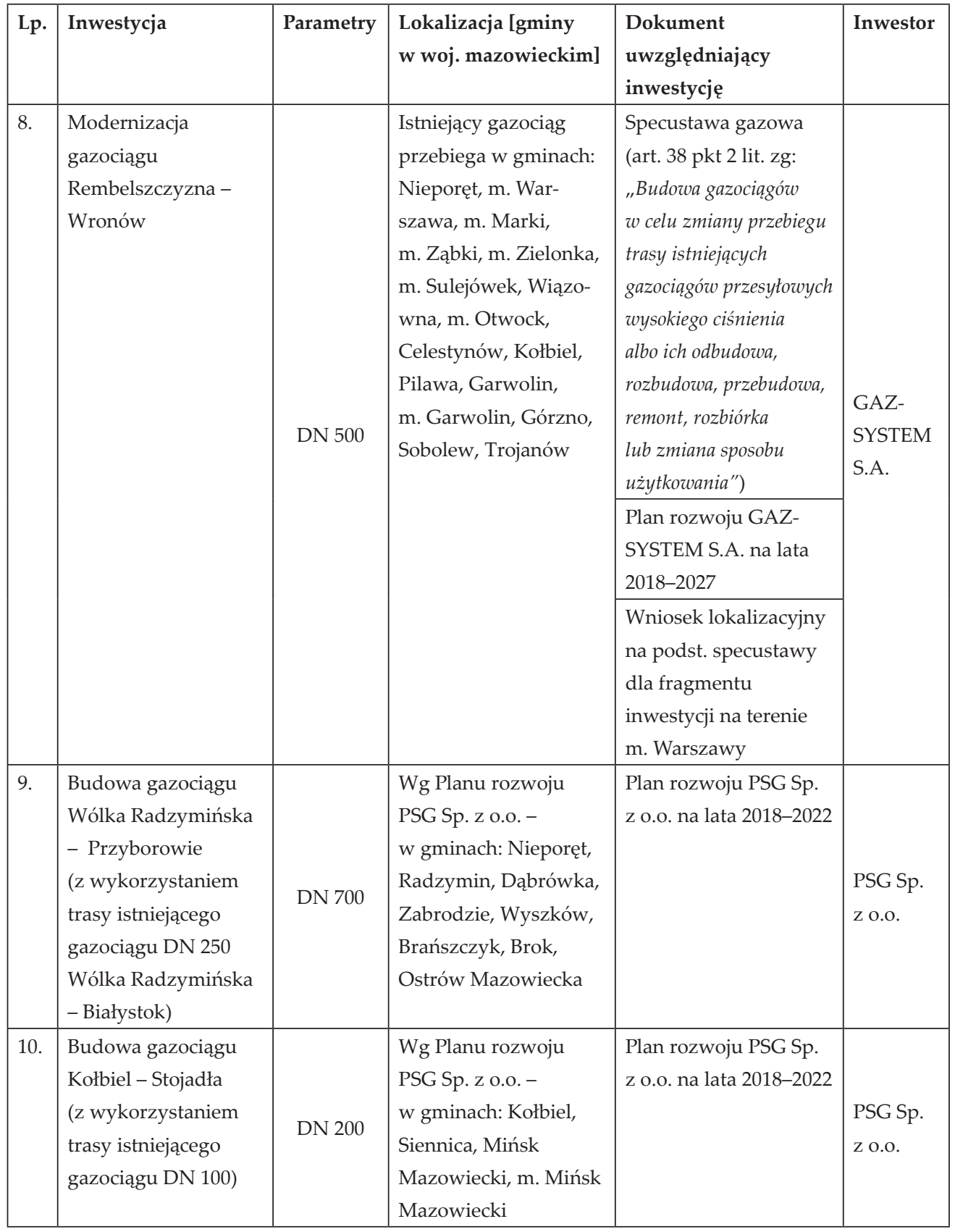




\begin{tabular}{|c|c|c|c|c|c|}
\hline Lp. & Inwestycja & Parametry & $\begin{array}{l}\text { Lokalizacja [gminy } \\
\text { w woj. mazowieckim] }\end{array}$ & $\begin{array}{l}\text { Dokument } \\
\text { uwzględniający } \\
\text { inwestycję }\end{array}$ & Inwestor \\
\hline 11. & $\begin{array}{l}\text { Przebudowa } \\
\text { (modernizacja) } \\
\text { gazociągu Gończyce } \\
\text { - Siedlce na odcinku } \\
\text { Gończyce - Jarczew } \\
\text { (I etap) }\end{array}$ & DN 300 & $\begin{array}{l}\text { Wg Planu rozwoju } \\
\text { PSG Sp. z o.o. - } \\
\text { w gminach: Sobolew, } \\
\text { Żelechów }\end{array}$ & $\begin{array}{l}\text { Plan rozwoju PSG Sp. } \\
\text { z o.o. na lata } 2018-2022\end{array}$ & $\begin{array}{l}\text { PSG Sp. } \\
\text { z o.o. }\end{array}$ \\
\hline 12. & $\begin{array}{l}\text { Budowa tłoczni gazu } \\
\text { Rybno i Ostrów } \\
\text { Mazowiecka (na } \\
\text { gazociągu Wólka } \\
\text { Radzymińska - } \\
\text { Przyborowie) }\end{array}$ & b. d. & $\begin{array}{l}\text { Wg Planu rozwoju } \\
\text { PSG Sp. z o.o. - } \\
\text { w gminach: Wyszków, } \\
\text { Ostrów Mazowiecka }\end{array}$ & $\begin{array}{c}\text { Plan rozwoju PSG Sp. } \\
\text { z o.o. na lata 2018-2022 }\end{array}$ & $\begin{array}{l}\text { PSG Sp. } \\
\text { z o.o. }\end{array}$ \\
\hline 13. & $\begin{array}{l}\text { Rozbudowa } \\
\text { tłoczni gazu } \\
\text { Rembelszczyzna }\end{array}$ & b. d. & Nieporęt & \begin{tabular}{l} 
Specustawa gazowa \\
(art. 38 pkt 2 lit. z: \\
„Budowa węztów \\
lub ttoczni gazu \\
o przepustowości nie \\
mniejszej niż 50000 \\
m3/h niezbędnych \\
do funkcjonowania \\
gazociagów \\
przesyłowych”) \\
\multicolumn{1}{c}{ KPZK } \\
Plan rozwoju GAZ- \\
SYSTEM S.A. na lata \\
2016-2025
\end{tabular} & $\begin{array}{l}\text { GAZ- } \\
\text { SYSTEM } \\
\text { S.A. }\end{array}$ \\
\hline 14. & $\begin{array}{l}\text { Modernizacja } \\
\text { tłoczni gazu } \\
\text { Rembelszczyzna }\end{array}$ & b. d. & Nieporęt & $\begin{array}{l}\text { Plan rozwoju GAZ- } \\
\text { SYSTEM S.A. na lata } \\
2018-2027\end{array}$ & $\begin{array}{l}\text { GAZ- } \\
\text { SYSTEM } \\
\text { S.A. }\end{array}$ \\
\hline 15. & $\begin{array}{l}\text { Modernizacja tłoczni } \\
\text { gazu Hołowczyce }\end{array}$ & b. d. & Sarnaki & $\begin{array}{l}\text { Plan rozwoju GAZ- } \\
\text { SYSTEM S.A. na lata } \\
2016-2025\end{array}$ & $\begin{array}{l}\text { GAZ- } \\
\text { SYSTEM } \\
\text { S.A. }\end{array}$ \\
\hline 16 & $\begin{array}{l}\text { Koncepcja } \\
\text { budowy gazociagu } \\
\text { przesyłowego gazu } \\
\text { łupkowego Wronów } \\
\text { - Gustorzyn }\end{array}$ & b. d. & W trakcie analiz & KPZK & $\begin{array}{l}\text { GAZ- } \\
\text { SYSTEM } \\
\text { S.A. }\end{array}$ \\
\hline & \multicolumn{5}{|c|}{ Inwestycje ustalone w specustawie gazowej } \\
\hline
\end{tabular}




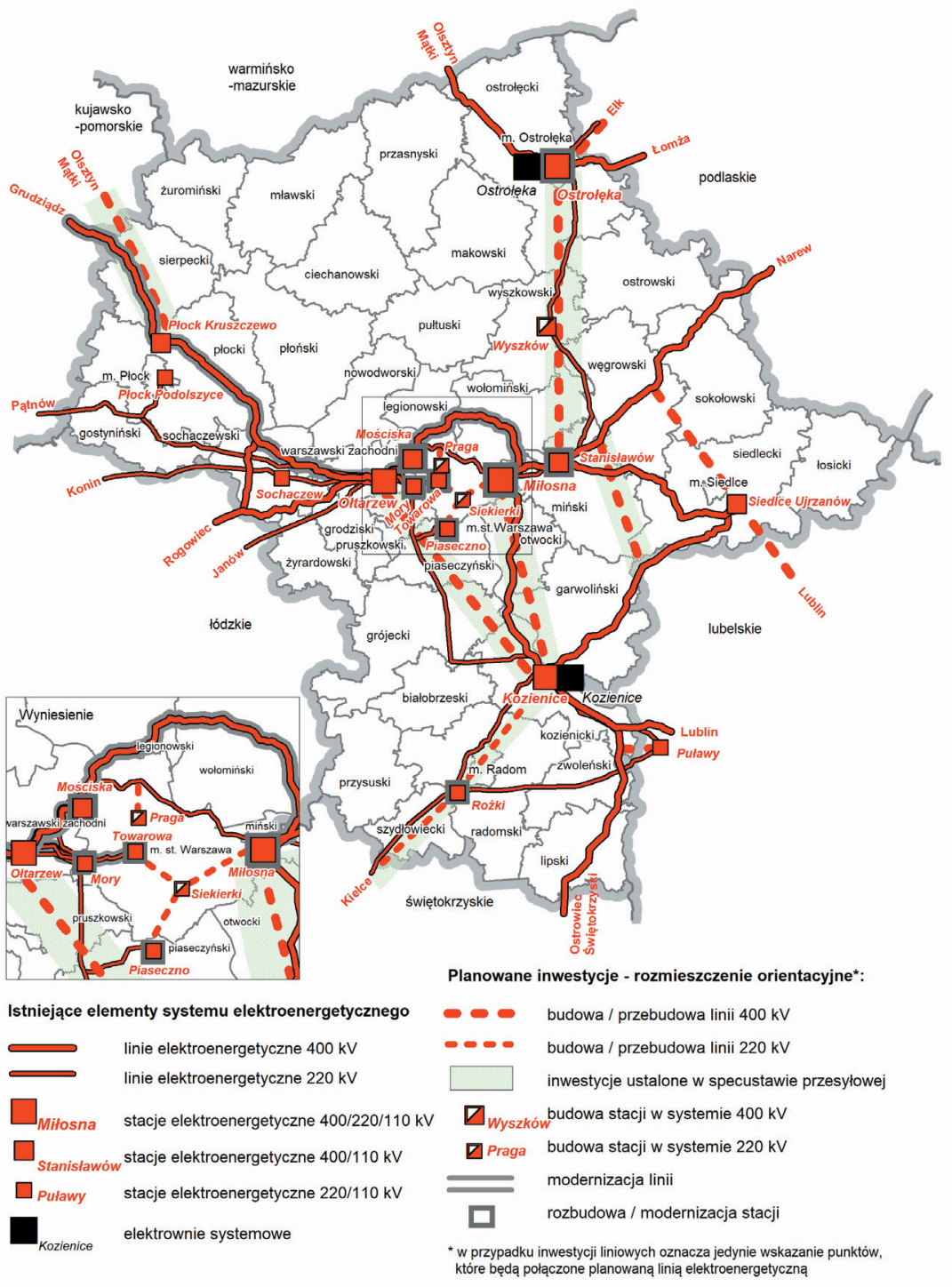

Ryc. 1. Planowane inwestycje w zakresie sieci elektroenergetycznych najwyższych napięć (stan na koniec $2018 \mathrm{r}$.)

Źródło: opracowanie MBPR na podstawie: specustawy przesyłowej, KPZK, LPS POliŚ, SOR, planów rozwoju i danych operatorów elektroenergetycznego systemu przesyłowego, decyzji lub wniosków lokalizacyjnych 


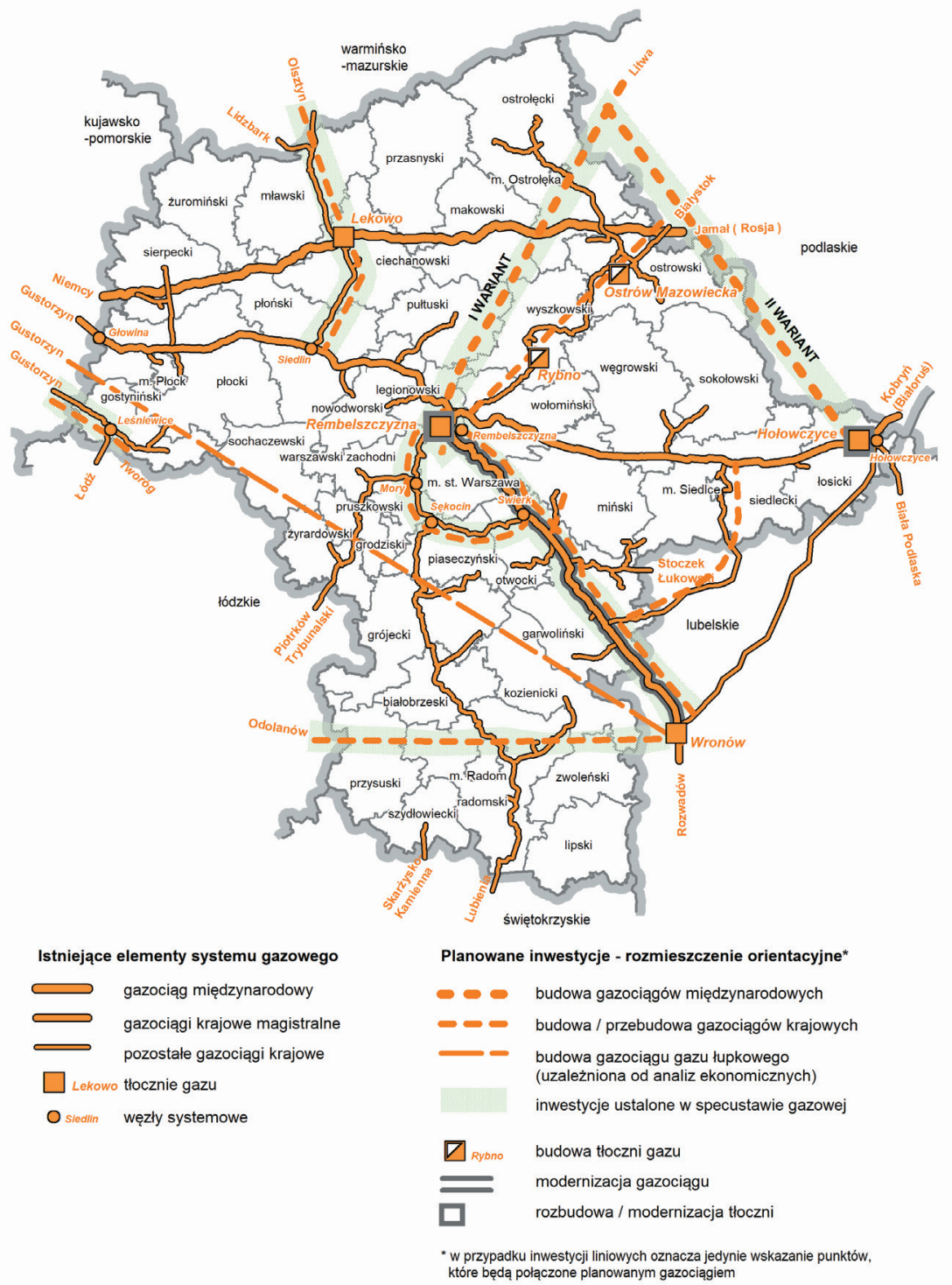

Ryc. 2. Planowane inwestycje w zakresie sieci gazowych wysokiego ciśnienia (stan na koniec 2018 r.) Źródło: opracowanie MBPR na podstawie: specustawy gazowej, KPZK, SOR, planów rozwoju i danych operatorów systemów gazowych wysokiego ciśnienia, decyzji lub wniosków lokalizacyjnych 


\section{Inwestycje energetyczne w dokumentach planowania przestrzennego}

Budowa i utrzymanie energetycznych sieci przesyłowych (transportowych) stanowi zgodnie z przepisami ustawy z dnia 21 sierpnia 1997 r. o gospodarce nieruchomościami - cel publiczny (do celów publicznych nie jest natomiast zaliczona budowa i utrzymanie obiektów i urządzeń do produkcji energii). Na podstawie ustawy z dnia 27 marca 2003 r. o planowaniu i zagospodarowaniu przestrzennym inwestycje celu publicznego uwzględniane są $\mathrm{w}$ dokumentach planistycznych województwa oraz gmin. W dokumentach gminnych obligatoryjnie należy umieścić ponadlokalne inwestycje z zakresu sieci energetycznych, ujęte $w$ planie zagospodarowania przestrzennego województwa oraz będące przedmiotem decyzji o ustaleniu lokalizacji, wydanych przez wojewodę na podstawie specustaw.

W planie zagospodarowania przestrzennego województwa umieszcza się „inwestycje celu publicznego o znaczeniu ponadlokalnym (...), które zostały ustalone w dokumentach przyjętych przez Sejm Rzeczypospolitej Polskiej, Radę Ministrów, właściwego ministra"1. W związku z powyższym Plan zagospodarowania przestrzennego województwa mazowieckiego (PZPWM) uwzględnia inwestycje energetyczne, określone w przedmiotowych dokumentach, $\mathrm{w}$ tym $\mathrm{w}$ specustawach energetycznych - mimo braku w tych przepisach jednoznacznie określonego wymogu umieszczenia przedmiotowych inwestycji w planie województwa. Taki obowiązek istnieje natomiast w odniesieniu do gminnych dokumentów planistycznych - wydana przez wojewodę decyzja o ustaleniu lokalizacji inwestycji „,wiąże właściwe organy przy sporządzaniu studium uwarunkowań i kierunków zagospodarowania przestrzennego oraz miejscowego planu zagospodarowania przestrzennego"². Oznacza to, że musi być ona uwzględniona przy sporządzaniu lub zmianie gminnych dokumentów planistycznych, nawet wtedy, gdy nie jest umieszczona w planie województwa.

$\mathrm{W}$ odniesieniu do inwestycji, które nie zostały ustalone $\mathrm{w}$ dokumentach poziomu krajowego, w PZPWM dopuszczono „planowanie i realizację urządzeń niewymienionych imiennie w Planie, a także przebudowę, rozbudowę i korekty tras sieci istniejących, jeśli będzie to miało na celu optymalizację funkcji technicznych systemów energetycznych, minimalizację uciążliwości dla środowiska lub usunięcie kolizji przestrzennych - pod warunkiem braku sprzeczności z innymi ustaleniami Planu. Powyższe dotyczy w szczególności działań na rzecz rozwoju przesyłowych i dystrybucyjnych sieci energetycznych, zawartych w planach rozwoju w zakresie zaspokojenia obecnego i przyszłego zapotrzebowania na energię i paliwa gazowe, które uzyskają pozytywną opinię Zarządu Województwa Mazowieckiego".

Studia uwarunkowań i kierunków zagospodarowania przestrzennego gmin województwa mazowieckiego na trasach planowanych linii elektroenergetycznych najwyższych napięć i gazociągów wysokiego ciśnienia, w zdecydowanej większości nie

\footnotetext{
${ }^{1}$ Według interpretacji ww. przepisu „stanowienie inwestycji celu publicznego o znaczeniu ponadlokalnym może nastąpić w różnych formach prawnych - w aktach prawa powszechnie obowiązującego (ustawy, rozporządzenia)" - Z. Niewiadomski (red.), Planowanie i zagospodarowanie przestrzenne, Komentarz, Warszawa 2016, s. 399.

${ }^{2}$ Zgodnie z art. 13 ust. 2 specustawy gazowej oraz art. 11 ust. 2 specustawy przesyłowej.
} 
uwzględniają tych zamierzeń lub uwzględniają je wyłącznie w zapisach, bez określenia ich lokalizacji na rysunkach. Nie będzie to jednak miało żadnego proceduralnego znaczenia dla realizacji inwestycji przygotowywanych i budowanych w trybie specustaw energetycznych, przewidzianym dla większości zamierzeń, których inwestorami są: PSE S.A. i GAZ-SYSTEM S.A.

\section{Podsumowanie}

W niniejszym artykule przeanalizowano i zbiorczo zestawiono zamierzenia inwestycyjne na terenie województwa mazowieckiego, planowane w ramach rozwoju sieci elektroenergetycznych najwyższych napięć oraz systemu gazowego wysokiego ciśnienia. Analiza dotyczyła inwestycji ujętych w dokumentach poziomu krajowego oraz w planach rozwoju przedsiębiorstw energetycznych, obowiązujących na koniec 2018 r. Znaczna część planowanych sieci i urządzeń podlega przepisom specustaw energetycznych, co oznacza możliwość realizacji inwestycji niezależnie od ustaleń wojewódzkich i gminnych dokumentów planowania przestrzennego.

W związku z tym, że inwestycje energetyczne budzą wielkie protesty społeczne, zasadnym było opracowanie kompleksowej informacji w tym zakresie, która może zostać wykorzystana przez samorządy gminne $\mathrm{w}$ procesach negocjacji $\mathrm{z}$ przedsiębiorstwami energetycznymi (inwestorami tych inwestycji) oraz konsultacji z mieszkańcami i organizacjami pozarządowymi.

W aktualnej sytuacji prawnej ustalenie lokalizacji przedmiotowych inwestycji może nastąpić w decyzji właściwego miejscowo wojewody, wydanej na podstawie specustawy gazowej lub specustawy przesyłowej na wniosek inwestora (w odniesieniu do zamierzeń uwzględnionych w tych przepisach) lub w wyniku działań planistycznych gmin, prowadzonych $\mathrm{w}$ ramach ich ustawowych kompetencji w zakresie planowania przestrzennego.

\section{Słownik skrótów:}

DN - średnica nominalna w $\mathrm{mm}$

EC - elektrociepłownia

GAZ-SYSTEM S.A. - Operator Gazociągów Przesyłowych GAZ-SYSTEM S.A.

KPZK - Koncepcja Przestrzennego Zagospodarowania Kraju 2030

kV - kilowolt

LNG ( $\mathrm{z}$ ang. liquefied natural gas) - skroplony gaz ziemny

LPS POIiŚ 2014-2020 - Lista Projektów Strategicznych dla infrastruktury energetycznej, w ramach Programu Operacyjnego Infrastruktura i Środowisko 2014-2020

m. - miasto

MPa - megapaskal

PSE S.A. - Polskie Sieci Elektroenergetyczne S.A.

PSG Sp. z o.o. - Polska Spółka Gazownictwa Sp. z o.o.

PZPWM, Plan - Plan zagospodarowania przestrzennego województwa mazowieckiego 
specustawa gazowa - ustawa z dnia 24 kwietnia 2009 r. o inwestycjach w zakresie terminalu regazyfikacyjnego skroplonego gazu ziemnego w Świnoujściu

specustawa przesyłowa - ustawa z dnia 24 lipca 2015 r. o przygotowaniu i realizacji strategicznych inwestycji w zakresie sieci przesyłowych

SOR - Strategia na rzecz Odpowiedzialnego Rozwoju do roku 2020 (z perspektywą do 2030 r.)

UE - Unia Europejska

\section{Literatura}

Niewiadomski Z. (red.), 2016 r., Planowanie i zagospodarowanie przestrzenne, Komentarz, C.H. Beck, Warszawa.

\section{Dokumenty i akty prawne}

Koncepcja Przestrzennego Zagospodarowania Kraju 2030, uchwała nr 239 Rady Ministrów z dnia 13 grudnia 2011 r. w sprawie przyjęcia Koncepcji Przestrzennego Zagospodarowania Kraju 2030 (M.P. z 2012 r. poz. 252).

Kontrakt Terytorialny dla Województwa Mazowieckiego, uchwała nr 233 Rady Ministrów z dnia 14 listopada 2014 r. w sprawie zatwierdzenia Kontraktu Terytorialnego dla Województwa Mazowieckiego (M.P. z 2014 r. poz. 1142).

Lista Projektów Strategicznych dla infrastruktury energetycznej w ramach Programu Operacyjnego Infrastruktura i Środowisko 2014-2020 (LPS POIiŚ 2014-2020), zatwierdzona przez Ministra Energii w dniu 29 października 2018 r.

Lista projektów wspólnego zainteresowania Wspólnoty Energetycznej (PECI), przyjęta Decyzją D/2016/11/MC-EnC Rady Ministrów Wspólnoty Energetycznej z dnia 14 października 2016 r.

Plan rozwoju Operatora Gazociagów Przesyłowych GAZ-SYSTEM S.A. w zakresie zaspokojenia obecnego i przyszłego zapotrzebowania na paliwa gazowe na lata 2016-2025, Warszawa, kwiecień 2016 r.

Plan rozwoju Operatora Gazociagów Przesyłowych GAZ-SYSTEM S.A. w zakresie zaspokojenia obecnego i przyszłego zapotrzebowania na paliwa gazowe na lata 2018-2027, Warszawa, listopad 2017 r.

Plan rozwoju Polskiej Spótki Gazownictwa Sp. z o.o. na lata 2018-2022, Warszawa, styczeń 2018 r.

Plan rozwoju Polskich Sieci Elektroenergetycznych S.A. w zakresie zaspokojenia obecnego i przyszłego zapotrzebowania na energię elektryczna na lata 2016-2025, Konstancin-Jeziorna, listopad 2015 r.

Plan rozwoju RWE Stoen Operator Sp. z o.o. w zakresie zaspokojenia obecnego i przyszłego zapotrzebowania na energię elektryczna na lata 2017-2022, Warszawa, 2016 r.

Plan zagospodarowania przestrzennego województwa mazowieckiego, uchwała nr 22/18 Sejmiku Województwa Mazowieckiego z dnia 19 grudnia 2018 r.(Dz.Urz. Woj. Maz. z 2018 r. poz. 13180). 
Strategia na rzecz Odpowiedzialnego Rozwoju do roku 2020 (z perspektywa do 2030 r.), uchwała nr 8 Rady Ministrów z dnia 14 lutego 2017 r. (M.P. z 2017 r. poz. 260).

Studia uwarunkowań i kierunków zagospodarowania przestrzennego gmin na trasach planowanych przesyłowych sieci energetycznych.

Ustawa z dnia 10 kwietnia 1997 r. Prawo Energetyczne (Dz.U. z 2018 r. poz. 755, z późn. zm.). Ustawa z dnia 21 sierpnia 1997 r. o gospodarce nieruchomościami (Dz.U. z 2018 r. poz. 2204, z późn. zm.).

Ustawa z dnia 27 marca 2003 r. o planowaniu i zagospodarowaniu przestrzennym (Dz.U. z 2018 r. poz. 1945).

Ustawa z dnia 24 kwietnia 2009 r. o inwestycjach w zakresie terminalu regazyfikacyjnego skroplonego gazu ziemnego w Świnoujściu (Dz.U. z 2017 r. poz. 2302, z późn. zm).

Ustawa z dnia 24 lipca 2015 r. o przygotowaniu i realizacji strategicznych inwestycji w zakresie sieci przesyłowych (Dz.U. z 2018 r. poz. 404).

Uzasadnienie do projektu ustawy o zmianie ustawy o inwestycjach w zakresie terminalu regazyfikacyjnego skroplonego gazu ziemnego w Świnoujściu oraz ustawy o gospodarce nieruchomościami (bip.msp.gov.pl/download/1/6276/UstawawrazzuzasadnieniemiOSR.pdf).

Uzasadnienie do projektu ustawy o zmianie ustawy o przygotowaniu i realizacji strategicznych inwestycji w zakresie sieci przesyłowych (http://www.sejm.gov.pl/sejm8.nsf/ druk.xsp?nr=1257).

\section{Strony internetowe}

http://www.inwestycje-w-energetyce.cire.pl/pliki/2/realizacjastrategicznychinwestycjiwzakr esiesieciprzesylowych.pdf

http://www.gaz-system.pl/fileadmin/centrum_prasowe/Rembelszczyzna-Mory_mapka.jpg http://www.gaz-system.pl/

https://www.psgaz.pl/

http://www.pse.pl/ 


\section{Planned development of energy transmission networks in Mazovia Voivodeship}

\section{ABSTRACT}

The article presents a summary of the applicable 2018 investment plans, outlined in various documents, concerning energy transmission networksin Mazovia Voivodeship.

Construction and reconstruction of the high-voltage power lines and high-pressure gas pipelines with accompanying infrastructure are government investments. They were carried out by state-owned energy companies. Only some of the planning investments (set out in documents adopted by the Sejm or government authorities) are obligatorily included in the Voivodeship spatial management plan. In recent years, the development of most of the planned transmission power networks is carried out according to the procedures set out in the two energy special acts: transmission and gas. According to their provisions, the regulations of spatial planning and land development do not apply to the decisions establishing the location of investments and obtaining a building permit. This means that it is possible to implement investment plans, which are not included in the regional and municipal planning documents.

Due to the fact, that energy investments rise great social protests, the creation of complete information in this area was justified. It can be used by local governments in the negotiation processes with energy companies and consultations with inhabitants and non-governmental organizations.

Key words: energy networks, investments, special acts

\footnotetext{
Urszula Gadomska - absolwentka Politechniki Warszawskiej, pracownik samorządowy, kontakt: Mazowieckie Biuro Planowania Regionalnego w Warszawie, Oddział Terenowy w Siedlcach, ul. Pułaskiego 19/21, 08-110 Siedlce, e-mail: ugadomska@mbpr.pl Urszula Gadomska - a graduate of the Warsaw University of Technology, public administration employee, contact: Mazovian Office for Regional Planning in Warsaw, Branch office in Siedlce, ul. Pułaskiego 19/21, 08-110 Siedlce, e-mail: ugadomska@mbpr.pl
}

Beata Gochnio - absolwentka Politechniki Warszawskiej, pracownik samorzq̨owy, kontakt: Mazowieckie Biuro Planowania Regionalnego w Warszawie, Oddział Terenowy w Siedlcach, ul. Pułaskiego 19/21, 08-110 Siedlce, e-mail: bgochnio@mbpr.pl Beata Gochnio - a graduate of the Warsaw University of Technology, public administration employee, contact: Mazovian Office for Regional Planning in Warsaw, Branch office in Siedlce, ul. Pułaskiego 19/21, 08-110 Siedlce, e-mail: bgochnio@mbpr.pl

Elżbieta Polak - absolwentka Szkoły Głównej Gospodarstwa Wiejskiego w Warszawie, pracownik samorzq̨owy, kontakt: Mazowieckie Biuro Planowania Regionalnego w Warszawie, Oddział Terenowy w Siedlcach, ul. Pułaskiego 19/21, 08-110 Siedlce, e-mail:epolak@mbpr.pl

Elżbieta Polak - a graduate of the Warsaw University of Life Sciences, public administration employee, contact: Mazovian Office for Regional Planning in Warsaw, Branch office in Siedlce, ul. Pułaskiego 19/21, 08-110 Siedlce, e-mail:epolak@mbpr.pl 